\title{
The Application of Critical Thinking in Teaching English Reading
}

\author{
Jun Xu \\ English Department of Dezhou University, Shandong, China \\ Email:xujun56cn@yahoo.com.cn
}

\begin{abstract}
Examining different critical thinking definitions, one thing is agreed upon by most researchers: that is critical thinking includes not only critical thinking skills (containing both a process of thinking and thinking ability), involving analysis, interpretation, inference, explanation, evaluation and self-regulation but also critical thinking dispositions including clarity, accuracy, precision, consistency, relevance, sound evidence, good reasons, depth, breadth, fairness. So a new way to teach English reading focusing on developing students' critical thinking should be proposed. Students should be trained to be critical readers who can "question, organize, interpret, synthesize, and digest what they read"
\end{abstract}

Index Terms - critical thinking, English teaching, English reading

\section{CONCEPT AND VARIOUS Definitions OF CRITICAL Thinking}

The concept of critical thinking has been refined and enriched since its appearance 2500 years ago. By looking through literature, various definitions were found to help one understand the nature of critical thinking. John Dewey (1993) is the first to define critical thinking as "reflective thinking... active, persistent, and careful consideration of a belief or supposed form of knowledge in light of the grounds which support it and the further conclusions to which it tends" (p.99-116) and John Dewey (1993) suggested a 5-phase critical thinking model which included (1) suggestions, (2) problem definition, (3) hypothesis generation, (4) reasoning and (5) hypothesis testing.

In this definition, Dewey states the necessity for individuals to actively and persistently participate in their own thinking process through reflections, giving reasons and interpretations to the conclusions and evaluate it. Learning improves in the process of reflective thinking.

Bloom (1956) terms critical thinking as the ability to gain knowledge through the exploration of ideas concerning the following six levels: knowledge, comprehension, application, analysis, synthesis, and evaluation. Knowledge and comprehension belong to the low level of thinking skills, while the other elements belong to the higher level of thinking skills.

William Huitt (1998) defines critical thinking that the disciplined mental activity of evaluating arguments or propositions and making judgments that can guide the development of beliefs and taking action.

Michael Scriven \& Richard Paul provided the most important features of critical thinking and intellectual standards. They describes critical thinking as the intellectual process of actively conceptualizing, applying, analyzing, synthesizing, and/or evaluating information gathered from, or generated by, observation, experience, reflection, reasoning, or communication, as a guide to belief and action. In its exemplary form, it is based on universal intellectual values that transcend subject matter divisions: clarity, accuracy, precision, consistency, relevance, sound evidence, good reasons, depth, breadth, and fairness (Scriven \& Paul, 1987).

Robert Ennis is another important person in developing critical thinking theories. He emphasized the practicability of critical thinking. Ennis (1991) terms critical thinking as "reasonable, reflective thinking that is focused on deciding what to believe or do." (p.6) His emphasis is on decision making about belief and action, the process of reflection and the rationality of reason. Critical thinking helps people to decide what to believe and how to solve various problems. He develops a streamline of critical thinking skills starting with open-mindedness and mindful of alternatives. A critical thinker should always try hard to widen the gap of his understanding of one topic and to be informed more about what one learns gives more rational reasons in one's critique. One's judgement of things will be more credible and reliable if one is well-informed. A well-informed person can identify conclusions and assumptions in an argument. In other words, A well-informed person is able to probe and find things that will support with evidence and be able to defend it in such a way that people will accept it. The model also proposes that a critical person asks relevant and legitimate questions that help to clarify things. By doing this, a learner can formulate hypothesis which can be tested in an experiment. Ennis (1985) also explains that creative acts such as formulating hypothesis, alternative ways of viewing a problem, questions, possible solutions, and plans for investigating things all belong to critical thinking.

Fisher(2001) describes critical thinking as " a kind of evaluated thinking — which involves both criticism and creative thinking and which is particularly concerned with the quality of reasoning and argument which is presented in support of a belief or a course of action" (p.13). Paul \& Elder (2005) summarize the essence of critical thinking as the art of thinking about thinking in two ways: 1) identify its strengths and weaknesses, and 2) recast it in improved form (where 
necessary). It requires the thinker to be skilled in analytic, evaluative and creative thinking. To Paul \& Elder, critical thinking is analysis of thinking by focusing on the parts or structures of thinking ("the Elements of Thought"), evaluation of thinking by focusing on the quality ("the Universal Intellectual Standards") and improvement of thinking by using what you have learned ("the Intellectual Traits"). This definition points out critical thinking as the "art of thinking" and the way to develop one's critical thinking ability through "thinking about thinking". The biggest contribution of Paul and Elder is that they added the dimension of intellectual standards to measure critical thinking.

In 1990, The Delphi Report gave the consensus statement about critical thinking by a group of experts:

We understand critical thinking to be purposeful, self-regulatory judgment which results in interpretation, analysis, evaluation, and inference, as well as explanation of the evidential, conceptual, methodological, criteriological, or contextual considerations upon which that judgment is based... The ideal critical thinker is habitually inquisitive, well-informed, trustful of reason, open-minded, flexible, fair-minded in evaluation, honest in facing personal biases, prudent in making judgments, willing to reconsider, clear about issues, orderly in complex matters, diligent in seeking relevant information, reasonable in the selection of criteria, focused in inquiry, and persistent in seeking results which are as precise as the subject and the circumstances of inquiry permit. (American Philosophical Association, 1990)

Examining different critical thinking definitions, one thing is agreed upon by most researchers: that is critical thinking includes not only critical thinking skills (containing both a process of thinking and thinking ability), involving analysis, interpretation, inference, explanation, evaluation and self-regulation but also critical thinking dispositions including clarity, accuracy, precision, consistency, relevance, sound evidence, good reasons, depth, breadth, fairness (Scriven \& Paul, 1987).

\section{RELATED THEORIES AND RESEARCHES ON CRITICAL THINKING}

\section{A. Benjamin Bloom 's Taxonomy}

Bloom's Taxonomy perhaps influences educators most in their teaching and thinking. Teachers often use Bloom's Taxonomy to design their lessons, make up test questions and assignments. Benjamin Bloom (1956) is the first person to classify human thinking skills into six major classes: 1) knowledge, 2) comprehension, 3) application, 4) analysis, 5) synthesis, 6) evaluation. Knowledge is defined as the remembering of previously learned material. It represents the lowest level of learning outcomes in the cognitive domain. In this level, students are required to search for objective answers to things such as "Who", "What", "When", "Where", and "How". Learning knowledge comes before anything such as comprehension or analysis. It should be thought of as the first step one takes when beginning one's critical look into a piece of text. For example, if one reads a book on the history of the Chinese Tang Dynasty, the first step the reader does is to obtain knowledge of history. They can use defining, describing, identifying, recognizing, stating and reciting. There need not, according to this model, to have too many preconcieved notions about the passage in the first reading, just read it so that there are objective facts in one's mind. In this way the students will be ready to form an initial understanding of the text. Comprehension follows knowledge. It is the ability to grasp the meaning of the material and goes just beyond. It takes what one has learned and interprets it into one's own words. Comprehension is the lowest level of understanding and it is a necessary skill to possess before being able to use the knowledge for any useful purpose. It may contain classifying, estimating, explaining, illustrating, predicting and summarizing. For example, if you learn about the history of Tang Dynasty, you do not just have the knowledge, but have a basic understanding of what the life was like at that particular period in history. Upon comprehension, you are able to communicate to others what you have learned about the key events of the Tang Dynasty. Application is the next area in the hierarchy and refers to the ability to use learned material in new and concrete situations. Application requires a higher level of understanding than comprehension. Application is always a major struggle for an educator because while one might have the enormous ability to comprehend obtainable knowledge, the question is always, "How do I apply this to what I am doing?" This level helps learners to apply, change, complete, defend, interpret, and translate. In analysis, the next area of the taxonomy, the learning outcomes require an understanding of both the content and the structural form of material. This is where a person has to become like an archaeologist, exploring, comparing, contrasting, investigating, researching, inferring, and examining. An archaeologist's job is to probe into one's findings. For example, if an archaeologist has discovered a mummy, he/she must go beyond their basic knowledge and understanding of this particular finding. He/she will want to find evidence to support exactly where the mummy is from, what are the important features, and so forth. This will help the archaeologist come to a conclusion about the mummy's identity. So, if a learner is reading a novel, they will form an in-depth discussion about the book. He/she will take it apart, piece by piece, in order to find the true meaning of the book. Because analysis calls for an understanding of something or someone in a subjective manner rather in an objective manner. Analysis is often used to prove whether something is correct. Lastly, it is often used to demonstrate the relevancy, usefulness, and qualities of knowledge learned. Without proper probing into knowledge, we will not know how it can be applied to whatever we are doing in our society. Next is synthesis, which refers to the ability to put parts together to form a new whole. Learning outcomes at this level stress creative behaviors with a major emphasis on the formulation of new patterns or structures. It helps bring thinkers to new stages of adapting, combining, developing, experimenting, imagining, predicting, and speculating. Synthesis calls for a learner's ability to try to see the bigger picture of whatever he/she has learned. This is where creativity plays a huge role in a student after obtaining some useful knowledge or skill. It gives a learner a chance to suggest their own ideas and 
solutions to the material they have learned. The learner becomes real participants of what he/she is reading or engages actively in a more direct way. Synthesis offers a learner a chance to create his/her own unique solutions or apply the theory in his/her work or personal life. Lastly, synthesis gives the learner a chance to form new perspectives. The learner no longer is just a student, but someone who is seriously challenging existing ideas. Synthesis is not emphasized enough in schools. It is an educator's responsibility to instill in a learner to not just to obtain knowledge, but to give them the motivation to think on their own and how they can contribute to what they have read, seen, or heard. The last level of the taxonomy is evaluation. Evaluation is concerned with the ability to judge the value of material for a given purpose. The judgments are to be based on definite criteria. Learning outcomes in this area are the highest in the cognitive hierarchy because they incorporate or contain elements of knowledge, comprehension, application, analysis, and synthesis, being able to assess, command, conclude, critique, and support their findings. In addition, they contain conscious value judgments based on clearly defined criteria (Bloom, 1956).

\section{B. The Revised Version of Bloom's Taxonomy}

During the 1990s, a former student of Bloom, Lorin Anderson, led a new assembly which met for the purpose of updating the taxonomy, hoping to add relevance for 21 st century students and teachers. The new version of the taxonomy changed the word form of the old version, from noun to verb. Knowledge becomes remember. Evaluation in the old version was changed to Evaluate and was put in the second from the bottom in the new version. Comprehension and synthesis were changed to understand and create. The following table is a detailed explanation of each component. The terminology in the revised version is more clear and exact to analyze the critical thinking skills in literature. The new terms are explained in the following. This paper will combine the two models to analyze the History of the Peloponnesian War by Thucydides as an example to show how critical thinking functions in a piece of text.

1. Remembering: Retrieving, recognizing, and recalling relevant knowledge from long-term memory.

2. Understanding: Constructing meaning from oral, written, and graphic messages through interpreting, exemplifying, classifying, summarizing, inferring, comparing, and explaining.

3. Applying: Carrying out or using a procedure through executing, or implementing.

4. Analyzing: Breaking material into constituent parts, determining how the parts relate to one another and to an overall structure or purpose through differentiating, organizing, and attributing.

5. Evaluating: Making judgments based on criteria and standards through checking and critiquing.

6. Creating: Putting elements together to form a coherent or functional whole; reorganizing elements into a new pattern or structure through generating, planning, or producing. (Anderson \& Krathwohl, 2001, p.67-68)

\section{Paul \& Elder's Framework}

Paul \& Elder's framework of critical thinking examines how human beings reason critically and creatively and perhaps is the most applicable and widely used framework at present USA. Many universities adopted this framework in promoting their education quality-University of Louisville (Ideas2Action Committee), Montclair State University (Research Academy for University Learning); Indiana University (Campus Writing Program). This framework contains three components: the elements of thought (reasoning), the intellectual standards that should be applied to the elements of reasoning, the intellectual traits associated with a cultivated critical thinker that result from the consistent and disciplined application of the intellectual standards to the elements of thought.

The elements of thought (reasoning) first indicates that each reason has purposes. This is to say that any acquired knowledge has some useful application or else has no meaning. Human beings by nature want to know why they have to learn and then they try to show great curiosity. Point of view is very essential to one's reasoning. A learner engages not just in one point of view, but in all possible angles of whatever he/she is analyzing. Each learner's point of view will use some useful attempts to solve any problems being discussed in any given situation or material presented. This element of human thought embodies a learner's capacity to see things in his own and other people's mind. In one way, point of view is the ability to look at a concept or idea in a broader sense rather than in a narrow view in order to grasp the meaning of something fully. This means that the point of view serves as an opportunity for their own perspectives or opinions to be influenced or challenged by other materials or people's views and ideas. A learner's goal is to find a final conclusion to the work and discovers new solutions and applicable knowledge. Our interpretations help us to research these final conclusions. The Paul-Elder's Critical Thinking Framework presents a formal standardization for universal intellectual reasoning. These standards help a critical thinker create quality reason. In Paul's (1995) notes that educators should at all times aiming for perfecting a student's performance. Firstly, clarity is always a challenge for students who are trying to communicate their ideas in a coherent way to their audience. For example, if a student writes a short story for a creative writing class, it may be so general and yet basic in detail that a reader might misinterpret the meaning of the story. So, an educator will point out someone in a story whose character is not been described in proper detail. Not only that, maybe there are details that are not necessary which in turn will make his character seem rather vague and misunderstood. Clarity ensures accuracy and precision. If the details are accurate and precise, a reader will have a better understanding of how this character fits into the story. The educators' job then, is to produce an accessible model for a student to use to help them to have more clarity in their story writing. If these intellectual standards are to be met, a teacher will demonstrate ways through anything that will motivate the student to look at one's story and see how it can be perfected so that the work turns out to be an exceptional work of literary art. Depth is always a student's least 
favourite in learning. Paul (1995) notes that he thinks most students are not actually scanning their own skills and do not have clear ideas of these standards. The obvious factors that make it difficult are not necessarily a lack of knowledge or understanding, but a student's low aspiration to produce his/her own concepts and ideas. A teacher needs to motivate his/her students to think more on their own. In this way, a student is able to create a quality work that is creative and more thought provoking. This should be done through careful evaluation of all the aspects of a student's work.

\section{ANALYSIS AND Discussion OF THE APPLICATION OF CRITICAL THINKING IN TEXTS AND TEACHING}

Having discussed relevant critical thinking theories prevalent in the present America, this part examines how critical thinking functions in the literary text, namely the History of the Peloponnesian War by Thucydides using Bloom's Taxonomy, the revised version of Bloom's Taxonomy and Paul-Elder's critical thinking framework to show how the writer has used a critical thinking category to further the narrative and/or make an argument and also to analyze the pros and cons of each model. Then based on the analysis of the application of critical thinking skills by the writer, a model to train students critical thinking skills in teaching the text will be developed.

Text Analysis of Thucydides' History of the Peloponnesian War

Thucydides begins his writing, "Thucydides, an Athenian, wrote the history of the war between the Peloponnesians and the Athenians, beginning at the moment that it broke out, and believing that it would be a great war and more worthy of relation than any that had preceded it". In Bloom's Taxonomy, the writer utilized the skills of both comprehension and synthesis (putting all the elements together to form a whole). In the revised version of Bloom's Taxonomy, the writer is using the skill of Summarizing (Abstracting a general theme or major points).

In using Richard Paul's Model to analyze the logic of this topic sentence, the writer is stating his purpose in writing the history of the war between the Peloponnesian and the Athenians.

\section{A MODEL FOR TEACHING ENGLISH READING \& CONCLUSION}

In a traditional English reading class, students are mainly trained to improve their language skills- first to enlarge vocabularies and then to improve reading comprehension ability. They are expected to obtain information or knowledge from the text and accept the ideas or viewpoints presented in the textbook. Most of the reading articles are literature works, humorous stories and scientific articles, but very few argumentary articles with strict logic (Wen et Liu, 2006). The reading exercises are often multiple- choice questions to test students' comprehension. The traditional lecturing and classroom activities are not very helpful in fostering students' critical thinking. So a new way to teach English reading focusing on developing students' critical thinking should be proposed. Students should be trained to be critical readers who can "question, organize, interpret, synthesize, and digest what they read" (Paul, 1995, p.491)

First, the reading materials chosen for teaching must arouse students' interest and motivation, providing challenge to their thinking. Nuttall (1982) lists some useful guidelines in selecting a text:

1. Tell the students things they don't already know.

2. Introduce them to new and relevant ideas, make them think about things they haven't thought about before.

3. Help them to understand the way other people feel or think.

4. Make them want to read for themselves.

5. Does the text challenge the students' level of foreign language?

6. If there are new lexical items, are they worth learning at this stage and not too numerous?

7. Are some of them understandable by means of inference from the context?

8. Does the test lend itself to intensive study?

9. Does it enable you to ask good questions or devise other forms of exploitation?

The above guidelines involve Nuttall's criteria in choosing a text--readability, suitability of content and authenticity of text.

Pirozzi (2003) defines critical reading as "very high-level comprehension of written material requiring interpretation and evaluation skills"(p.325) and "it also entails using reference to go beyond what is stated explicitly, filling in informational gaps, and coming to logical conclusions"(p.325). So critical reading emphasizes the active nature of reading. The readers are not simply receiving the facts and knowledge in the text, but try to form their own opinions and viewpoints about what they read from the texts. In language teaching, according to Wallace (1999), critical means "both a preparedness to question and reflect on the meaning and uses of language" and it argues for "the need to draw attention to the ideological bases of discourses as they circulate both in everyday life and within specific texts" (p.98). The reading class should train critical readers. Therefore, critical readers "question, organize, interpret, synthesize, and digest what they read (Paul, 1995, p.491).

On the basis of theory discussion and the writers' own teaching experiences, the research proposes a five-step model to promote critical thinking in teaching English reading class.

First step: Pre-reading--Introduction of background or cultural knowledge to students.

According to Nunan's (2000) schema theory, cultural or background knowledge is more important than grammar complexity in reading comprehension. In this step, not like the traditional way of how teachers lecture to students the relevant knowledge, but teachers activate students' knowledge about the topic. Before reading, teachers should ask 
students to read the title, the first or last paragraph or topic sentence of each paragraph. Then they ask the students to talk about their knowledge about the topic, predict the content. In this way, students' desire to read the text will be aroused. This method is used by Robert Gagne in his nine instructional events. (http://tip.psychology.org/gagne.html).

Second step: comprehension of the text and explicating the main idea of each paragraph.

Understanding phrases and sentences of a text is still very important to foreign language learners. But this should not be done through teachers explaining word by word and sentence by sentence. A critical reading class should encourage students to guess or infer meaning by context clues. Teachers should encourage students to elicit the main idea of each paragraph based on their own thinking of the content.

Third step: analyzing the logic of the text. In this step, Paul's Elements of Thought is a useful tool. The students should be encouraged to ask the following questions:

What is the key question the author is trying to answer?

What is the author's fundamental purpose?

What is the author's point of view with respect to the issue?

What assumptions is the author making in his or her reasoning?

What are the implications of the author's reasoning?

What information does the author use in reasoning through this issue?

What are the most fundamental inferences or conclusions in the article?

What are the author's most basic concepts? (Paul, 2008, p.10)

Fourth step: evaluating the logic of the text.

As evaluation is one of the key critical thinking skills, assessing the logic of the reading text helps bringing reading and thinking ability to a higher level. In this stage, Paul's Intellectual Standards is suggested to apply. The following questions help assess the logic of a text:

Does the author clearly state his or her meaning, or is the text vague, confused, or muddled in some way?

Is the author accurate in what he or she claims?

Is the author sufficiently precise in providing details and specifics when specifics are relevant?

Does the author introduce irrelevant material, thereby wandering from his/her purpose?

Does the author take us into the important complexities inherent in the subject, or is the writing superficial?

Does the author consider other relevant points of view, or is the writing overly narrow in its perspective?

Is the text internally consistent, or does the text contain unexplained contradictions?

Is the text significant, or is the subject dealt with in a trivial manner?

Does the author display fairness, or does the author take a one-sided, narrow approach? (Paul, 2008, p.11)

In answering the questions in the third and fourth step, peer work, group discussions and other cooperative learning are classroom techniques that can be utilized by teachers. Fogarty \& McTighe (1993) point out that cooperative learning enhances thinking processes. Through cooperative learning, students share their thoughts with each other and thus engage in an interactive approach to processing information. A key component of co-op learning is the reflection by group members.

Fifth Step: Writing.

In this stage, after comprehending and evaluating of the text, students will be required to write summaries, commentaries, reading journals, create similar stories or composing similar style argument of their own. This step trains the students' higher level of thinking skills--synthesis and application. This stage has the language teaching theory explanation by Brown (2001), "reading ability will best be developed in association with writing, listening and speaking activity. Even in those courses that may be labeled 'reading', your goals will best be achieved by capitalizing on the interrelationship of skills, especially the reading-writing connection". (p.283)

In a world, in this model, first and second steps aim at text interpretation, third and fourth steps focus on text evaluation, the fifth one is on reader's reaction. It concludes that this model throws a very different and efficient light upon teaching English reading. Of course, it needs to be improved in the practise. As a result, suggestions are greatly needed from all experts and scholars to make the model functional perfectly.

\section{REFERENCES}

[1] American Philosophical Association. (1990). Critical Thinking: A Statement of Expert Consensus for Purposes of Educational Assessment and Instruction. "The Delphi Report," Committee on Pre-College Philosophy. ERIC Doc. No. ED 315423.

[2] Anderson, L. W., \& Krathwohl, D. R. (2001). (Eds.). A taxonomy for learning, teaching and assessing: A revision of Bloom's Taxonomy of educational objectives: Complete edition. New York: Longman.

[3] Bloom B. S. (1956). Taxonomy of Educational Objectives. Handbook I: The Cognitive Domain. New York: David McKay Co Inc.

[4] Dewey, J. (1933. 9). How We Think: A Restatement of the Relation of Reflective Thinking to the Educative Process. Boston: Health.

[5] Ennis, R. (1985). Goals for a Critical Thinking/Reasoning Curriculum. Illinois Critical Thinking Project. University of Illinois, Champaign, IL.

[6] Fisher, A. (2001). Critical Thinking: An Introduction. Cambridge: Cambridge University Press.

[7] Huitt, W. (March, 1993). Critical thinking: An overview. Educational Psychology Interactive. Valdosta, GA: Valdosta State 
University. 1998. Retrieved Aug. 7th 2009 from http://chiron.valdosta.edu/whuitt/col/cogsys/critthnk.html. [Revision of paper presented at the Critical Thinking Conference sponsored by Gordon College, Barnesville, GA.

[8] Christine, Nuttall. (1982). Teaching Reading Skills in a Foreign Language. Heinemann Education.

[9] Paul, Richard. (1995). Critical Thinking: How to Prepare Students for a Rapidly Changing World. CA: Foundation for Critical Thinking.

[10] Paul, R. \& Elder, L. (2001, 2008).The miniature guide to critical thinking: Concepts and tools. Dillon Beach, CA: Foundation for Critical Thinking--How to read a paragraph Dillon Beach, CA: Foundation for Critical Thinking.

[11] Pirozzi, R. (2003). Critical Reading, Critical Thinking. New York: Longman.

[12] Scriven, M. (1985). Critical for survival. National Forum, Vol 55, p. 9-12.

[13] Wen, Q. F. \& et Liu, R. Q. (March 2006). An Exploratory Study on Features in English Majors' Abstract Thinking in English Argumentative Compositions. Journal of Foreign Languages, No.2.

Jun Xu was born in Binzhou, China in 1956. She majored in English Linguistics and Literature in the department of Foreign Studies, Liaocheng University, China in 1976-1979 and completed equivalent M.A. degree courses on English Linguistics and Literature in Shandong University, Jinan, China in 2002. Supported by Chinese State-funded students studying abroad Project, she was a full-time Visiting Scholar in School of English Study, Nottingham University, UK in 2002-2003.

She is currently an associate professor and the Director of the School of Foreign Languages, Dezhou University, Shandong, China. She has written "Study on analysis of Students' Speaking Error and PETS-Instruction of Students' Speaking Error Analysis in English Speaking Teaching”, Vladivostock, Russia: Intelligent Potential of Advanced Education-Development of Russian Far East and Asia-Pacific Development, 2009; "Experiencing in Glamorous Language World", Yantai, China: Journal of Yantai Education Institute, 2004; "Backwash Effect on Current High School English Teaching in light of NMET", Shandong Enterprise Education, 2007; Translation works: The Cambridge Illustrated History of British Theatre', Shandong Pictorial Press. 2006. Her research interests include cross-cultural communication and English language teaching.

$\mathrm{Ms} \mathrm{Xu}$ is the Director of English Language Institute of Shandong Province. Her publications as "Antidotes to Computer Virus" was awarded the third prize by the $8^{\text {th }}$ Dezhou Municipal Excellent Social Scientific Achievements in 1995; "Influence of English and American Language and Culture on Chinese Language" was awarded the third prize by the $9^{\text {th }}$ Dezhou Municipal Excellent Social Scientific Achievements in 1996; "Basic Exploration on Fast-reading Teaching" was awarded the third prize by the $17^{\text {th }}$ Dezhou Municipal Excellent Social Scientific Achievements in 2004. 